\title{
EFFECTS OF COMPOSITION ON THE IN-REACTOR
}

\section{CREEP OF AISI 316}

\section{MASTER}

J. F. Bates

E. R. Gilbert

August 1979

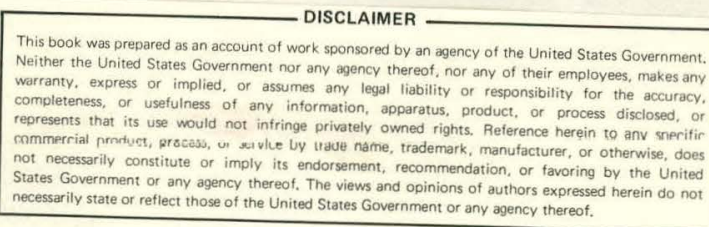

HANFORD ENGINEERING DEVELOPMENT LABORATORY

Operated by Westinghouse Manford Company, a subsidiary of Westinghouse Electric Corporation, under the Department of

Energy Contract Mo. DE-ACT4-76FFO2170 


\section{DISCLAIMER}

This report was prepared as an account of work sponsored by an agency of the United States Government. Neither the United States Government nor any agency Thereof, nor any of their employees, makes any warranty, express or implied, or assumes any legal liability or responsibility for the accuracy, completeness, or usefulness of any information, apparatus, product, or process disclosed, or represents that its use would not infringe privately owned rights. Reference herein to any specific commercial product, process, or service by trade name, trademark, manufacturer, or otherwise does not necessarily constitute or imply its endorsement, recommendation, or favoring by the United States Government or any agency thereof. The views and opinions of authors expressed herein do not necessarily state or reflect those of the United States Government or any agency thereof. 


\section{DISCLAIMER}

Portions of this document may be illegible in electronic image products. Images are produced from the best available original document. 
EFFECTS OF COMPOSITION OH THE IN-REACTOR

\title{
CREEP OF AISI 316
}

\author{
J. F. Bates and E. R. Gilbert
}

\section{Abstract}

In-reactor tests designed to provide information on the relationship between compositional variations and irradiation-induced swelling and creep have achieved an exposure of $4.6 \times 10^{22} \mathrm{n} / \mathrm{cm}^{2}$ ( $E>0.1 \mathrm{MeV}$ ) at $450^{\circ} \mathrm{C}$.

Postirradiation diametral measurements of pressurized tube specimens have indicated that irradiation-induced creep of 316 stainless stee? can be modified by compositional variations of minor alloying elements. There is a general trend for specimens with higher swelling to exhibit higher creep. Silicon, phosphorus and molybdenum all retard in-reactor creep and inhibit irradiation-induced swelling as well. However, the relationship between creep and swelling is strongly composition dependent. The data suggest that carbon and nitrogen act synergistically with the major influence being the nitrogen concentration. The irradiation-induced creep is insensitive to cobalt variations to the fluences investigated. 
EFFECTS OF COMPOSITION ON THE IN-REACTOR CREEP OF AISI 316

\author{
J. F. Bates and E. R. Gilbert
}

Hanford Engineering Development Laboratory

Introduction

The performance of fast breeder reactors is partly dependent upon the irradiation creep and swelling behavior of the core structural materials. It is therefore desirable to reduce the magnitude of these phenomena in the materials used for fuel pin cladding and ducts; the current reference material for these components is AISI 316 stainless steel. Experimental results pertaining to the effect of variations in composition of AISI 316 stainless steel have been 1 imited to comparison of different heats $(1,2)$ and different thermomechanical treatments. $(3,4)$. Except for the determination of the influence of $\mathrm{Ti}$ on in-reactor creep, ${ }^{(3)}$ the test discussed in this report is the first to deal directly with the effect of compositional variables on irradiation creep of AISI 316 stainless steel. The alloys utilized are identical to those used. previously to investigate the effects of composition on swelling.

\title{
Experimental Details
}

The specimens were fabricated from $0.64 \mathrm{~cm}$ diameter rod stock which was in the $20 \%$ cold worked condition. The compositions of the rods are given in Table 1. The specimens were manufactured by first grinding the rods to a $0.58 \mathrm{~cm}$ diameter and then, after cutting the rods into $3.8 \mathrm{~cm}$ lengths, drilling a hole $2.5 \mathrm{~cm}$ deep with a $0.51 \mathrm{~cm}$ diameter into one end. A cap was welded onto the open end and ear.h tube was pressurized to generate a hoop stress of $172 \mathrm{MPa}$ during irradiation at $450^{\circ} \mathrm{C}$. The specinens, figure 1 , consisted of a pressurized portion for determining irradiation creep and a solid portion for determining stress-free swelling. The diameter of each specimens was measured to $7.5 \times 10^{-5} \mathrm{~cm}$ before irradiation with an LVDT probe system. After neutron irradiation in EBR-II to $4.6 \times 10^{22} \mathrm{n} / \mathrm{cm}^{2}$ ( $\mathrm{E}>0.1 \mathrm{MeV}$ ) at $450^{\circ} \mathrm{C}$, the diameters were measured with a laser interferometer system to $2.5 \times 10^{-5} \mathrm{~cm}$.

Results

The data are listed in Table 2. The first column describes the primary composition variable. The second colume represents three times the fractional diameter increase of the unstressed solid end. The percentage diametra: increase for cold worked AISI 316 stainless steel was generally found to be similar to one-third of the percentage change in imilersion density to within 
$0.05 \%$. The irradiation creep strain is presented in column three and represents the increase in the diameter of the pressurized portion of the specimen less that of the unstressed portion to provide a correction for swelling. The last column on Table 2 represents the diameter increase of the pressurized portion of the specimen and includes the contributions of both irradiation creep and swelling.

\section{Discussion}

The results presented in Table 2 clearly show that variations in composition have a significant effect on irradiation creep. To further display the effects of the compositional variables, the irradiation creep strain is plotted versus the composition variables in weight percent in Figure 2. Except for cobalt additions the irradiationcreepstrain drops sharply as the solute content is increased.

The heat treatment given AISI 316 stainless steel has been demonstrated to be a factor which affects irradiation creep. (4) An aged specimen of AISI 316 stainless steel undergoes considerably more irradiation creep than a cold worked or solution treated specimen. The high amount of irradiation creep in the aged material has been attributed to depletion of carbon from the matrix. Irradiation creep in the high nitrogen alloy of the current test was suppressed below the value for the nominal AISI 316 stainless steel alloy even though this alloy had a low carbon content. It is significant to note, however, that high carbon in Alloy 4 in Table 1 was not effective in suppressirig creep when it was present without a significant amount of nitrogen. This demonstrates that the effect of carbon depends not only on the total amount present, but also upon how the carbon is distributed. It also suggests that the reason for the high irradiation creep ratcs in aged AISI 376 stainless steel may be related to nitrogen distribution in addition to carbon.

A comparison between the swelling and irradiation creep is made in Figures 3 through 7. The effect of sclute concentration on swelling and irradiation creep generally proceeds in the same direction. The irradiation creep strain is plotted versus the swelling in Figure 8 . There appears to be a general trend of increasing irradiation creep with increasing swelling; however, the large amount of scatter indicates that more data are needed to determine if there is a general correlation between irradiation creep and swelling for all the alloys. An analysis of specific modifications indicates that the proportionality is compositionally dependent as indicated in Figure 8.

The high cobalt alloy in Figure 3 is observed to display more densification than the other alloys. This provides a key as to the ineffectiveness of co on reducing irradiation creep. The densification indicates that a considerable amaunt 
of precipitation occurred in the high cobalt alloy; it is postulated that the elements which were effective in solution to suppress irradiation creep were instead present in the form of precipitates.

The results suggest that a stainless steel alloy containing approximately the nominal amounts of Mo, Si, Pand C, as given in Table 1 for alloy 3 , is a reasonable compromise for irradiation creep resistance. However, the irradiation creep could be further reduced by the addition of approximately $0.1 \mathrm{wt}$. $\% \mathrm{~N}$, although other properties such as strength and ductility would not favor a high nitrogen level.

\section{Conclusions}

The results of this study indicate that the irradiationcreep of $20 \%$ cold worked AISI 316 stainless steel can be reduced with controlled compositicn modifications of selected elements. Irradiation creep is retarded by $S i, P$, Ilo, and $N$, but appears to be insensitive to $C$ and $C o$ to the fluences investigated in this experiment.

There is a general trend for specimens with more swelling to exhibit more creep as well, but the proportionality between creep and swelling is strongly composition dependent. The specimens with low Si and low P content showed some swelling and large amounts of irradiation creep. However, specimens with low Ho and low $N$ content exhibited little swelling, but significant amounts of irradiation creep.

\section{$\underline{\text { References }}$}

1. A. J. Lovell and E. R. Gilbert, "Temperature Dependence of irradiation Creep in $20 \% \mathrm{CW} 316$ Stainless Steel," International Conference on Radiation Ef.. fects in Breeder Reactor Structural Materials, Scottsdale, AZ, June 1977.

2. A. J. Lovell, E. R. Gilbert and D. R. Duncan, "Thermal Creep in $20 \% \mathrm{CW}$ 316 Stainless Steel Heat K81531," submitted to Journal of Engineering Materials and Technology.

3. M. M. Paxton, B. A. Chin, E. R. Gilbert and R. E. Nygren, "Comparison of the In-Reactor Creep of Selected Ferritic, Solid Solution Strengthened, and Precipitation Hardened Commercial-Alloys," Jour. Nuc. Mat'15, 80, 1979, 144-151.

4. L. C. Walters, G. L. McVay and G. D. Hudman, "Irradiation-Induced Creep in 316 and 304L Stainless Steels," International Conference on Radiation Effects in Breeder Reactor Structural Materials, Scottsdale, AZ, June 1977.

5. J. F. Bates, "Irradiation-Induced Swelling Variations Resulting from Compositional Modifications of Type 316 Stainless Steel," ASTM STP 570, 197.5, $36 y-38 \%$. 
TABLE ]

ALLOY COMPOSITIONS

\begin{tabular}{|c|c|c|c|c|c|c|c|c|c|c|c|c|}
\hline \multirow{2}{*}{$\begin{array}{l}\text { Alloy } \\
\text { Number }\end{array}$} & \multicolumn{12}{|c|}{ Element (Weight \%). } \\
\hline & C & Mn & $\mathrm{Si}$ & $P$ & S & $\mathrm{Cr}$ & $\mathrm{Ni}$ & Mo. & $\mathrm{Cu}$ & Co & B & $i$ \\
\hline \multicolumn{13}{|c|}{ Carbon-Nitrogen Variations } \\
\hline $\begin{array}{r}3 \\
4 \\
45\end{array}$ & $\begin{array}{l}0.047 \\
0.127 \\
0.012\end{array}$ & $\begin{array}{l}0.94 \\
0.96 \\
1.12\end{array}$ & $\begin{array}{l}0.39 \\
0.38 \\
0.41\end{array}$ & $\begin{array}{l}0.010 \\
0.012 \\
: .010\end{array}$ & $\begin{array}{l}0.007 \\
0.008 \\
0.007\end{array}$ & $\begin{array}{l}16.99 \\
17.06 \\
16.93\end{array}$ & $\begin{array}{l}12.05 \\
12.08 \\
12.12\end{array}$ & $\begin{array}{l}2.33 \\
2.32 \\
2.31\end{array}$ & $\begin{array}{l}0.10 \\
0.10 \\
0.10\end{array}$ & $\begin{array}{l}0.12 \\
0.11 \\
0.11\end{array}$ & $\begin{array}{l}0.0008 \\
0.0010 \\
0.0012\end{array}$ & $\begin{array}{l}0.050 \\
0.006 \\
0.13\end{array}$ \\
\hline \multicolumn{13}{|c|}{ Phosphorus-Sulfur-Boron 'Jariations } \\
\hline $\begin{array}{r}6 \\
12\end{array}$ & $\begin{array}{l}0.048 \\
0.046\end{array}$ & $\begin{array}{l}0.92 \\
0.93\end{array}$ & $\begin{array}{l}0.35 \\
0.36\end{array}$ & $\begin{array}{l}0.001 \\
0.039\end{array}$ & $\begin{array}{l}0.004 \\
0.004\end{array}$ & $\begin{array}{l}16.89 \\
17.01\end{array}$ & $\begin{array}{l}11.99 \\
12.12\end{array}$ & $\begin{array}{l}2.36 \\
2.33\end{array}$ & $\begin{array}{l}0.12 \\
0.11\end{array}$ & $\begin{array}{l}0.12 \\
0.11\end{array}$ & $\begin{array}{l}0.0005 \\
0.00 C 5\end{array}$ & $\begin{array}{l}0.054 \\
0.057\end{array}$ \\
\hline \multicolumn{13}{|c|}{ Silicon Variations } \\
\hline $\begin{array}{l}25 \\
29\end{array}$ & $\begin{array}{l}0.046 \\
0.045\end{array}$ & $\begin{array}{l}0.95 \\
0.94\end{array}$ & $\begin{array}{l}0.01 \\
1.96\end{array}$ & $\begin{array}{l}0.010 \\
0.010\end{array}$ & $\begin{array}{l}0.008 \\
0.007\end{array}$ & $\begin{array}{l}16.88 \\
17.13\end{array}$ & $\begin{array}{l}11.98 \\
12.39\end{array}$ & $\begin{array}{l}2.37 \\
2.41\end{array}$ & $\begin{array}{l}0.10 \\
0.11\end{array}$ & $\begin{array}{l}0.11 \\
0.11\end{array}$ & $\begin{array}{l}0.0011 \\
0.0010\end{array}$ & $\begin{array}{l}0.052 \\
0.050\end{array}$ \\
\hline \multicolumn{13}{|c|}{ Molybdenum Variations } \\
\hline 30 & 0.044 & 0.39 & 0.40 & 0.010 & 0.007 & 16.89 & 12.31 & 0.01 & 0.10 & 0.11 & $0.001 t_{i}$ & 0.049 \\
\hline \multicolumn{13}{|c|}{ Cobalt Variations. } \\
\hline 39 & 0.042 & 0.90 & 0.38 & 0.011 & 0.008 & 17.00 & 12.04 & 2.30 & 0.10 & 4.45 & 0.0013. & 0.049 \\
\hline
\end{tabular}


TABLE $\cdot 2$

EFFECT OF SELECTED ELEMENTS ON IRRADIATION CREEP OF $20 \%$ COLD WORKED 316 STAINLESS STEEL AT $172 \mathrm{MPa}, 450^{\circ} \mathrm{C}$ AND $4.6 \times 10^{22} \mathrm{n} / \mathrm{cm}^{2}(E>0.1 \mathrm{MeV})$

\begin{tabular}{|c|c|c|c|}
\hline Comprsition & $\begin{array}{l}\text { Sivelling* } \\
\Delta V / V_{0} \\
(\%)\end{array}$ & $\begin{array}{c}\text { Irradiation Creep** } \\
\Delta \mathrm{D} / \mathrm{D}_{\mathrm{O}} \\
(\%)\end{array}$ & $\begin{array}{l}\text { Total l***. } \\
\Delta \mathrm{D} / \mathrm{D}_{\mathrm{O}} \\
(\%)\end{array}$ \\
\hline Niominal & 0.02 & 0.78 & 0.79 \\
\hline Low Si & 0.86 & 1.86 & 2.15 \\
\hline High Si & -0.03 & 0.46 & 0.45 \\
\hline Low $P$ & 0.68 & 3.28 & 3.51 \\
\hline High P & 0.005 & 0.39 & 0.39 \\
\hline Low Mo & 0.20 & 2.24 & 2.31 \\
\hline High Co & -0.26 & 0.76 & 0.68 \\
\hline Low N, Migh C & -0.056 & 1.41 & 1.40 \\
\hline High $\mathrm{N}$, Low C & -0.014 & 0.38 & 0.38 \\
\hline
\end{tabular}

* $3 \times \triangle D / D_{0}$ on unstressed solid cylinder.

** Total $\Delta D / D_{0}-\Delta V / 3 V_{0}$.

$\star \star \star$ Heasured on stressed tube. 
1. Pressurized. Tube Specimens Used in the Creep-Swelling Test.

2. Diameter Change as a Function of Solute Content.

3. Creep and Swelling:versus Molybdenum Content.

4. Creep and Swelling versus Cobalt Content.

5. Creep and Swelling versus Siliçon Content.

6. Creep and Swelling versus Nitrogen Content.

7. Creep and Swelling versus Phosphorus Content.

8. Creep and Swelling Interaction in all Alloys. 


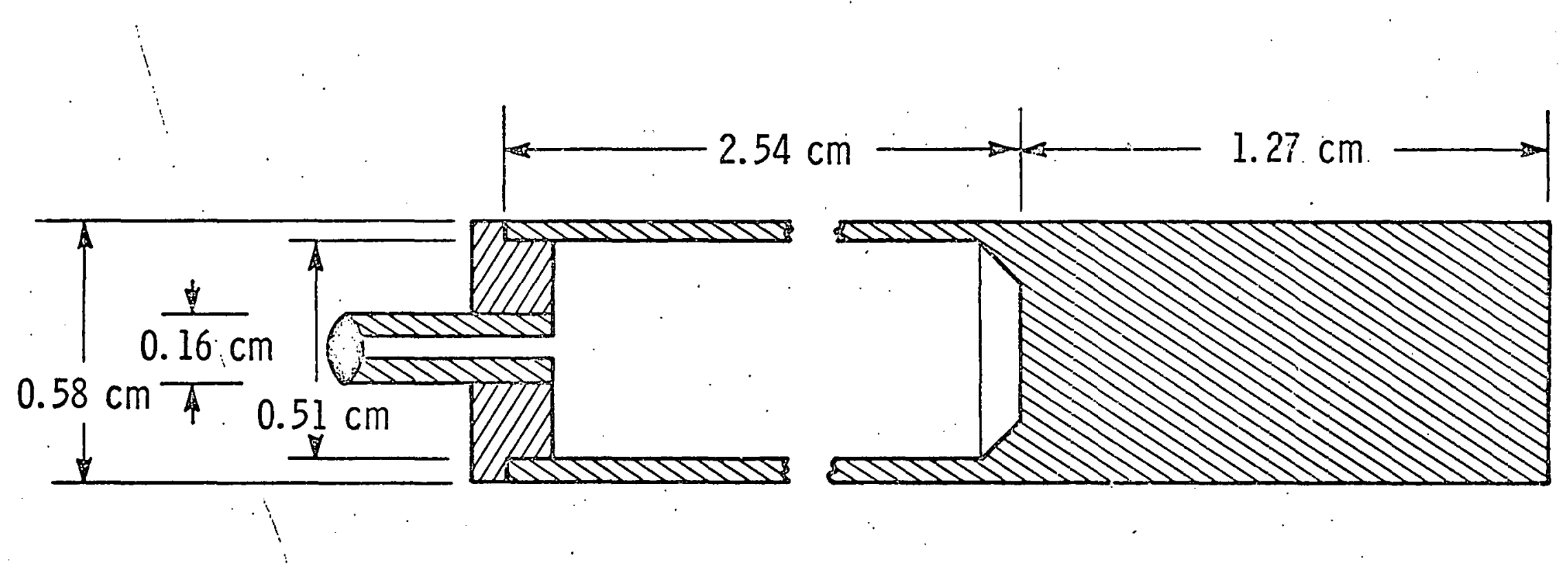

HEDL $7710-244.8$ 


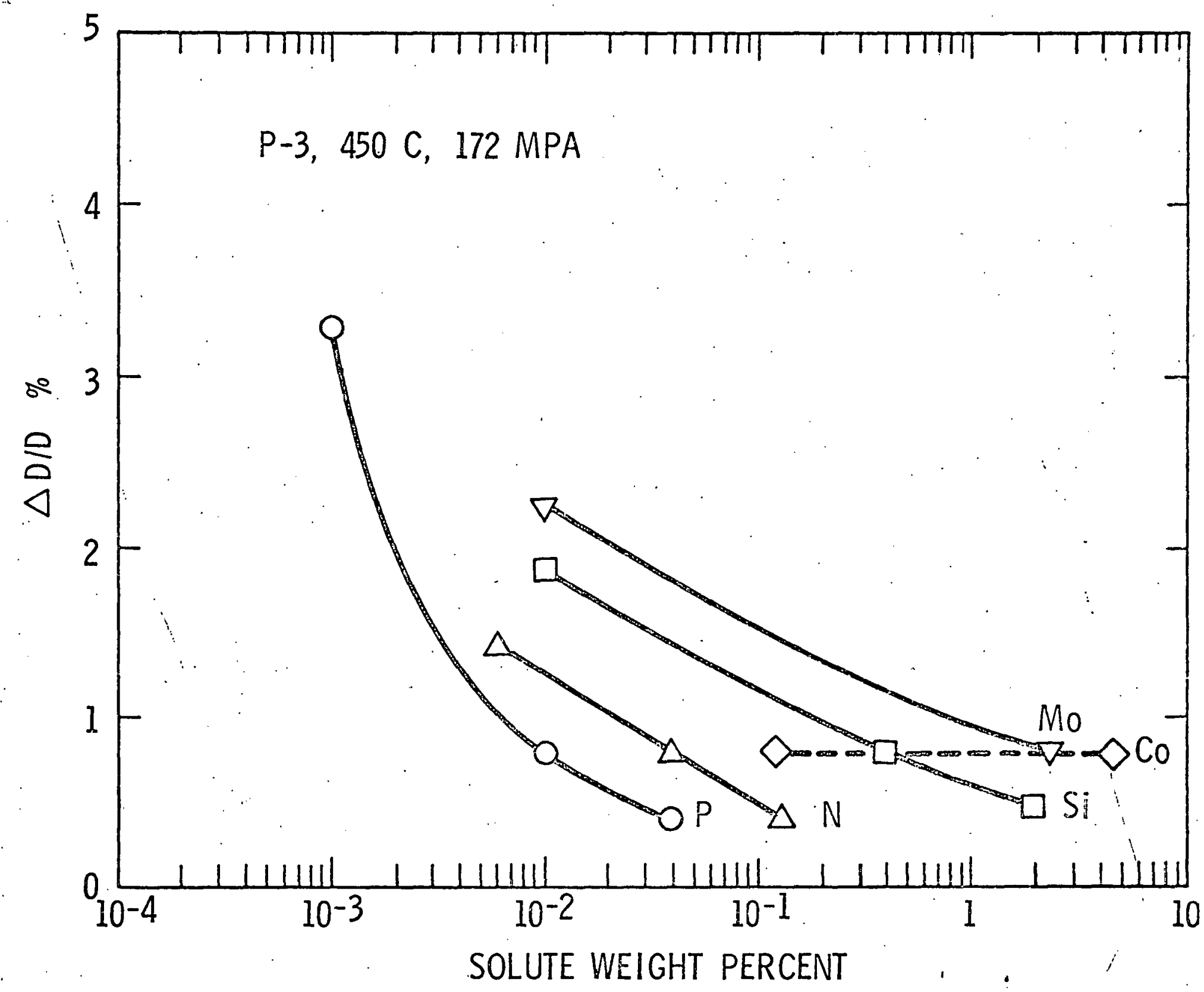

HEDL 7710-244.6 


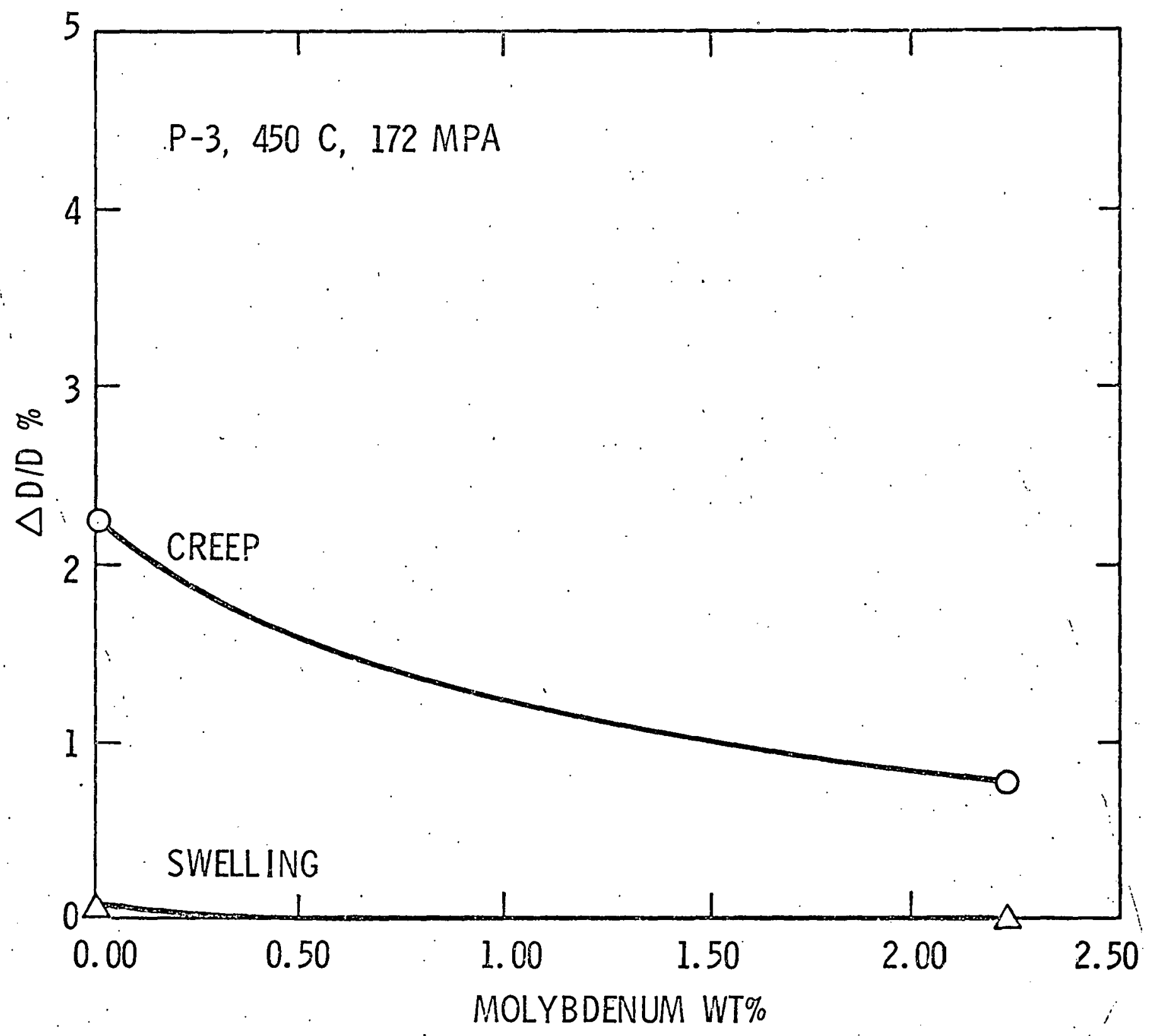

HEDL $7710-244.5$ 


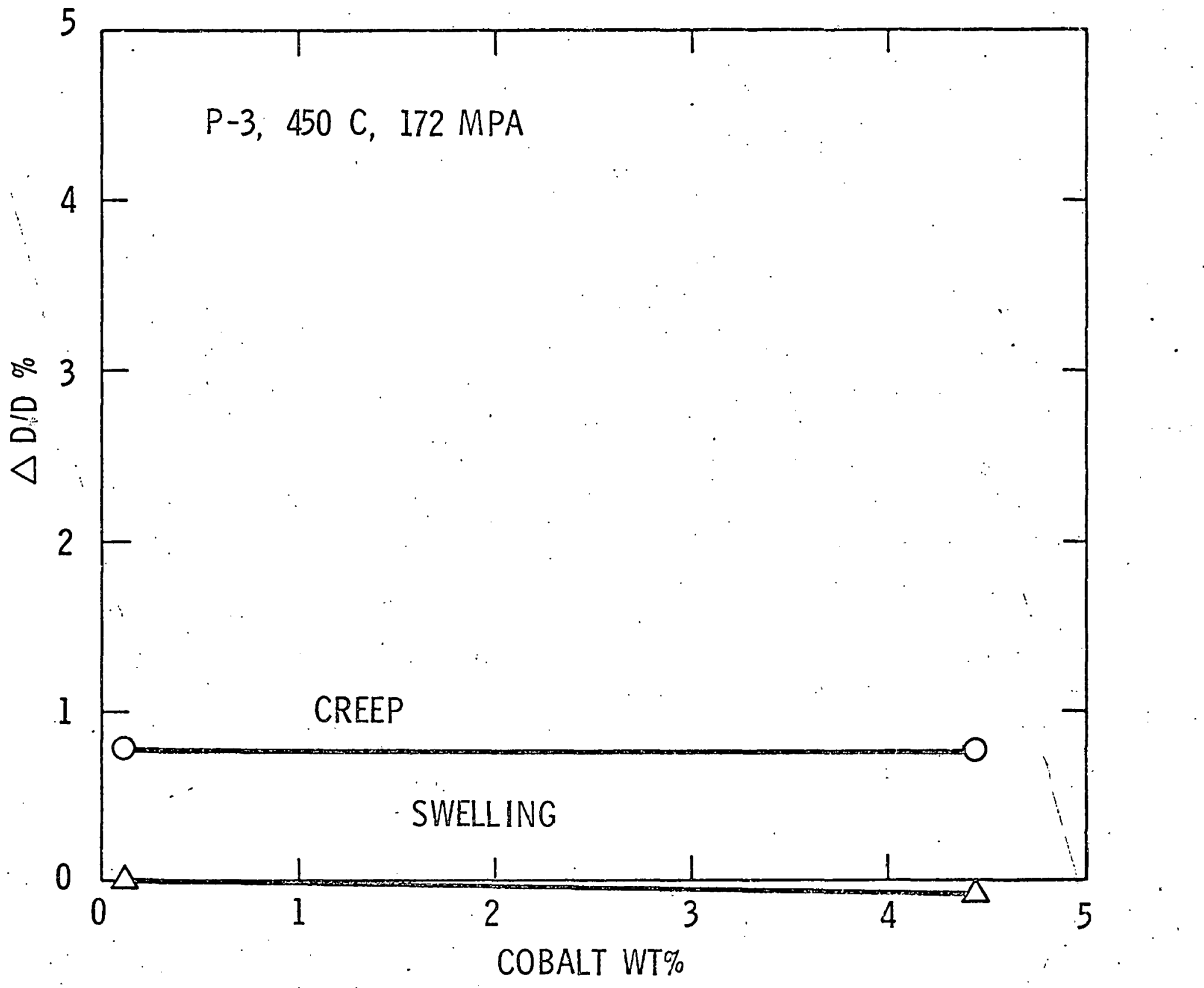

HEDL 7710-244.1 


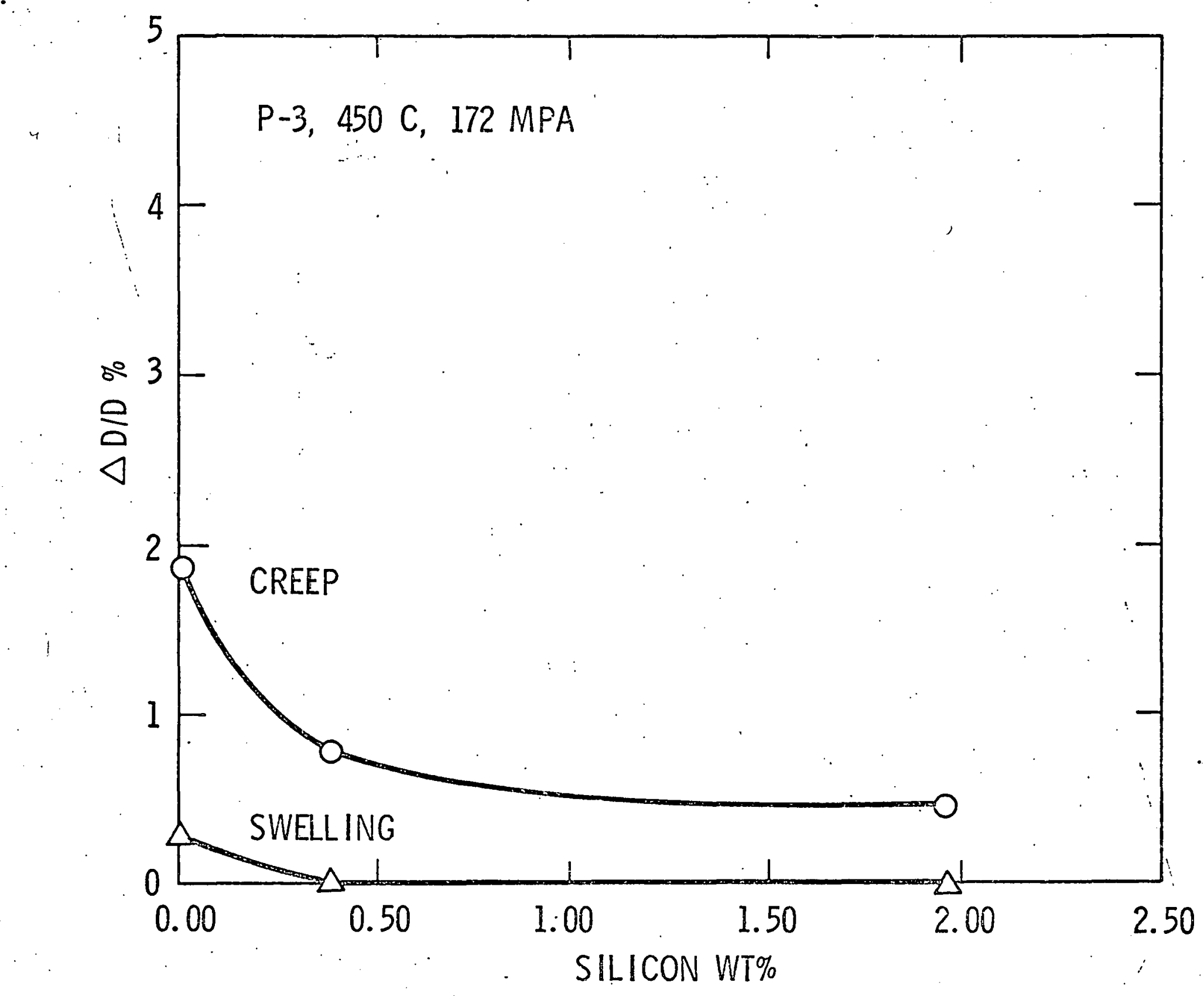

HEDL $7710-244.3$ 


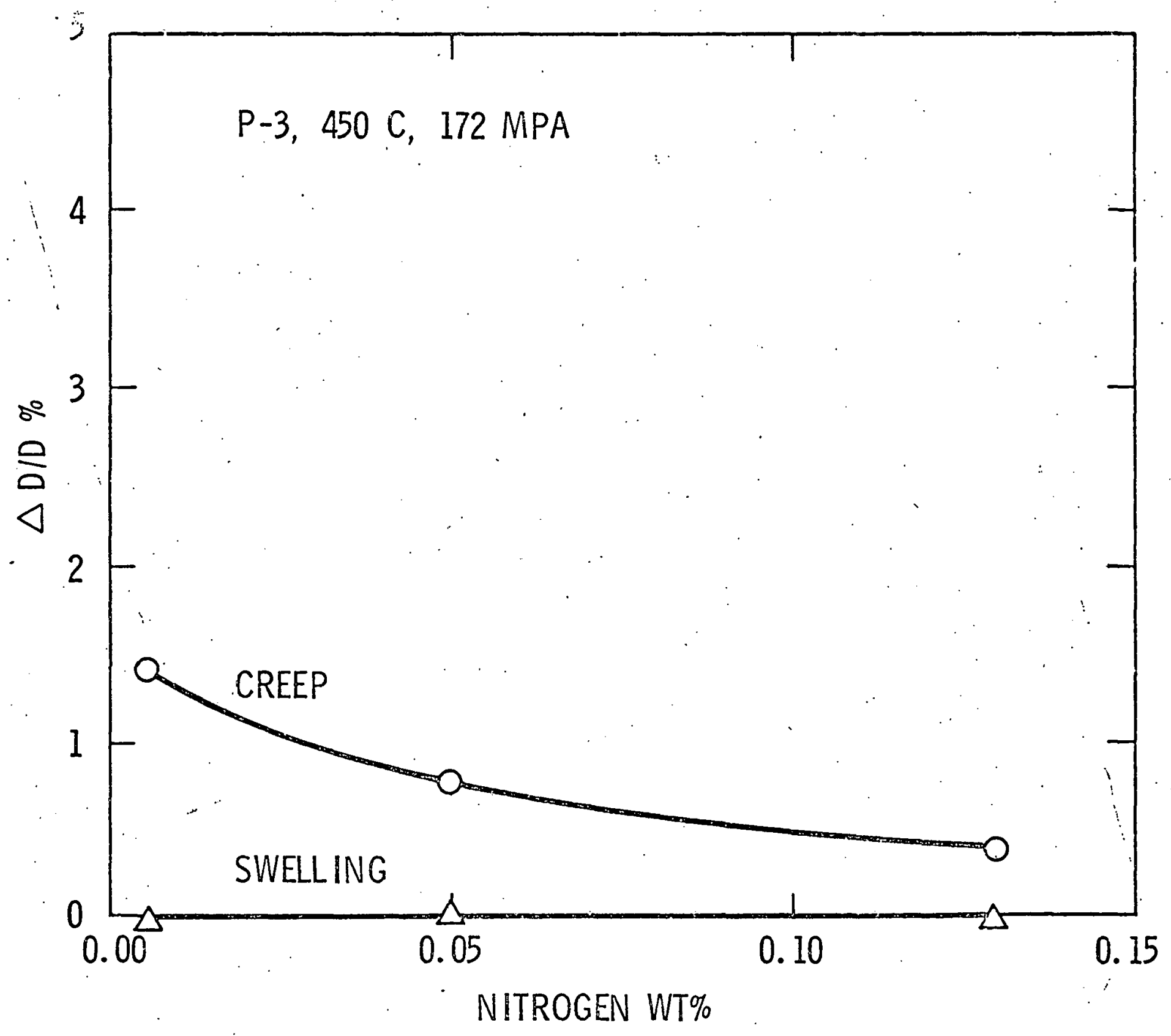

HEDL $7710-244.2$ 


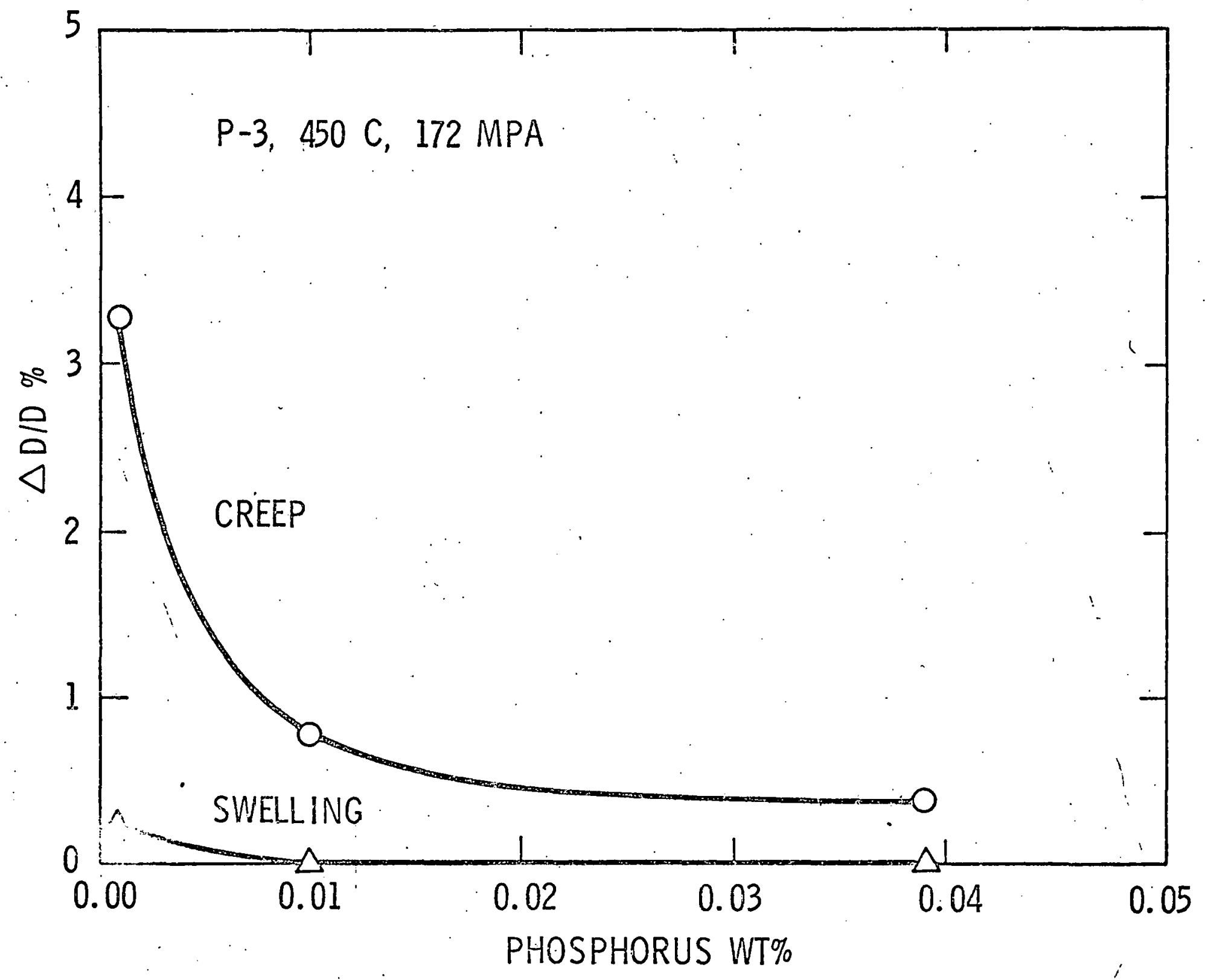

HEDL 7710-244.4 


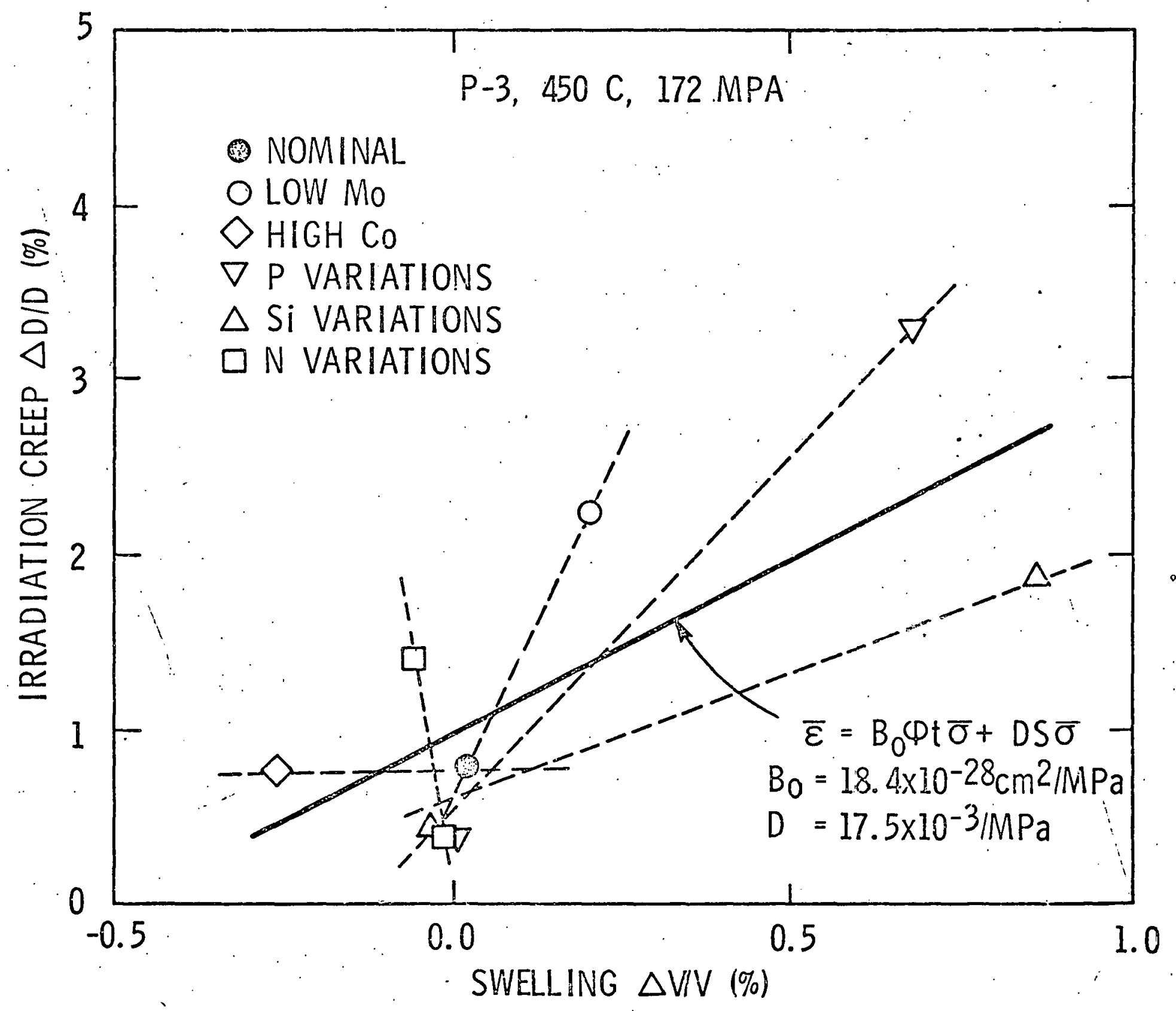

HEDL 7710-244.7 